\begin{tabular}{cl|l}
$\begin{array}{c}\text { Cellular Physiology } \\
\text { and Biochemistry }\end{array}$ & Cell Physiol Biochem 2012;30:49-60 & \\
\cline { 2 - 3 } DOI: 10.1159/000339045 & $\begin{array}{l}\text { O 2012 S. Karger AG, Basel } \\
\text { www.karger.com/cpb }\end{array}$ \\
\cline { 2 - 3 } & Published online: June 8, 2012 & $1015-8987 / 12 / 0301-0049 \$ 38.00 / 0$
\end{tabular}

\title{
Role of IRAK1 on TNF-induced Proliferation and NF- $\kappa$ B Activation in Human Bone Marrow Mesenchymal Stem Cells
}

\author{
Jong Myung Kim ${ }^{1,2}$ Hyun Hwa Cho ${ }^{1,2}$ Sun Young Lee ${ }^{1,2}$ Chang Pyo Hong ${ }^{1,2}$ Ji \\ won Yang ${ }^{1,2}$ You Sun Kim ${ }^{3}$ Kuen Tak Suh ${ }^{4}$ Jin Sup Jung ${ }^{1,2,5}$ \\ ${ }^{1}$ Department of Physiology, School of Medicine, Pusan National University, ${ }^{2}$ Medical Research Center \\ for Ischemic Tissue Regeneration, ${ }^{3}$ Institute for Medical Sciences, Ajou University School of Medicine, \\ Suwon, ${ }^{4}$ Department of orthopedic surgery, School of Medicine, Pusan National University, ${ }^{5}$ Medical \\ Research Institute, Pusan National University, Yangsan
}

\section{Key Words}

hBMSCs $・$ TNF- $\alpha \cdot$ IRAK1 $・$ ERK signaling $・ N F-\kappa B$

\begin{abstract}
In this study, we determined the effect of TNF- $\alpha$ on hBMSCs proliferation as well as the role of IL-1 receptor-associated kinase 1 (IRAK1) on TNF- $\alpha$ signaling. Western blot analysis revealed that TNF- $\alpha$ treatment increased the phosphorylation of IRAK1 in hBMSCs. The downregulation of IRAK1 inhibited TNF- $\alpha$-induced NF- $\mathrm{KB}$ activation and COX-2 expression. TNF- $\alpha$ treatment increased $\mathrm{hBMSC}$ proliferation in a dose-dependent manner and increased ERK, JNK, and NF- $\kappa B$ activity. U0126, an ERK inhibitor, decreased hBMSCs proliferation and significantly blocked TNF- $\alpha$-induced hBMSCs proliferation. In cells with IRAK1 or TRADD downregulation, the U0126 treatment inhibited hBMSCs proliferation and significantly suppressed TNF- $\alpha$ induced hBMSCs proliferation. The downregulation of IRAK1 or TRADD inhibited TNF- $\alpha$ induced ERK and JNK activation, and hBMSCs proliferation. Inhibition of NF- $\mathrm{KB}$ by decoy oligonucleotides reduced the TNF- $\alpha$-induced hBMSCs proliferation. Immunoprecipitation analysis showed that IRAK1 does not physically interact with TNF receptor 1 (TNFR1) even in the presence of TNF- $\alpha$. Suppression of IRAK1 binding protein (IRAK1BP1) inhibited TNF- $\alpha$ induced increase of the proliferation and ERK1 phosphorylation of hBMSCs in the presence of TNF- $\alpha$. Our data indicate that TNF- $\alpha$ modulates hBMSCs proliferation through ERK signaling pathways, and that IRAK1 plays an important role in TNF- $\alpha$-induced NF- $\mathrm{KB}$ activation in hBMSCs.
\end{abstract}




\begin{tabular}{rl|l} 
Cellular Physiology & \multicolumn{1}{c}{\begin{tabular}{l} 
Cell Physiol Biochem 2012;30:49-60 \\
\cline { 2 - 3 } DOI: 10.1159/000339045
\end{tabular}} & \\
and Biochemistry & $\begin{array}{l}\text { Published online: June 8, 2012 } \\
\text { www.karger.com/cpb }\end{array}$ \\
\cline { 2 - 3 } Kim/Cho/Lee/Hong//ang/Kim/Suh/Jung: The Role of IRAK1 on hBMSCs Proliferation
\end{tabular}

\section{Introduction}

Adult mesenchymal stem cells (MSCs) can be isolated from bone marrow or marrow aspirates, and can be expanded in culture while retaining their multipotency; they can differentiate into a variety of cell types, including osteoblasts, chondrocytes, myocytes, adipocytes, $\beta$-pancreatic islets cells, and possibly neuronal cells. MSCs are of therapeutic interest because they have low immunogenicity as well as the availability of autologous cells. Indeed, human clinical trials are now under way to use allogenic MSCs to treat myocardial infarcts, graft-versus-host disease, Crohn's Disease, cartilage and meniscus injury, stroke, and spinal cord injury [1]. Transplanted MSCs are exposed to a harsh microenvironment that includes hypoxia, inflammation, and immune response. Therefore, by understanding the interaction between transplanted MSCs and the microenvironment, we hope to discover information useful to predict the in vivo fate of transplanted cells. TNF- $\alpha$ is a multi-functional cytokine that regulates cellular immune function, cell differentiation, proliferation, apoptosis, and energy metabolism, and it contributes to the pathophysiology associated with osteoporosis, insulin resistance, and atherogenesis [2,3]. TNF- $\alpha$ is induced by various injuries and conditions and is mainly responsible for the localized response, including inflammation and apoptosis [4]. It has been well established that TNF- $\alpha$ induces MSCs to produce numerous cytokines, including vascular endothelial growth factor, insulin-like growth factor 1, and hepatocyte growth factor (HGF) [5, 6], all of which are considered angiogenic and anti-inflammatory factors. The preconditioning of MSCs with TNF- $\alpha$ increases in vivo engraftment in the myocardial infarction model [7]. Genetic ablation of TNF receptors inhibited MSC-mediated protection against myocardial ischemic injury [8].

It has been reported that TNF- $\alpha$ modulates the differentiation potential and proliferative abilities of MSCs; it inhibits adipogenic differentiation $[9,10]$. Recently, we and other investigators reported that increased osteogenic differentiation results from NF- $\mathrm{KB}$ activation [11]. Opposing effects of TNF- $\alpha$ on MSC proliferation have also been reported. Boker et al. reported that TNF- $\alpha$ caused an increase in the invasive and proliferative properties of human bone marrow-derived mesenchymal stem cells (hBMSCs) [12], but Ghali et al. reported that TNF- $\alpha$ induced an inhibition of the proliferative and apoptotic properties of hBMSCs [13].

The best known TNF signaling pathway is NF- $\mathrm{KB}$ pathway through TNF receptor 1 (TNFR1) activation. The membrane associated complex of ligand-engaged TNFR1 with TNFR1-associated death domain protein (TRADD), TNF receptor-associated factor 2 (TRAF2), and receptor-interacting protein (RIP) results in the activation of NF- $\kappa B, E R K$, JNK, p38 MAP kinase, and ceramide/sphingomyelinase pathways [14-21]. The complexity of TNFR1-mediated signaling permits many divergent outcomes (i.e., proliferation, activation, and apoptosis) to occur as a result of TNF signaling.

Interleukin-1 receptor-associated kinases (IRAKs) are a unique family of death domaincontaining protein kinases that play a key role in the signaling cascades of 2 receptor families: Toll-like receptors (TLRs) and IL-1 receptors (IL-1Rs) [22]. Vig et al. first reported that IRAK1 plays an important role in TNF- $\alpha$ signaling in the C3H1-T1/2 mouse embryo fibroblast cell line [23]. Our previous study showed that the downregulation of IRAK1 by overexpression of miR-146 inhibits both TNF- $\alpha$-induced NF- $\mathrm{KB}$ activation and osteogenic differentiation in human adipose tissue-derived mesenchymal stem cells (hADSCs) [11]. However, the role of IRAK1 on TNF- $\alpha$ signaling is still not clear in human mesenchymal stem cells (MSCs).

In this study, we determined the role of IRAK1 on TNF-induced proliferative changes and on NF- $\mathrm{\kappa B}$ activation in human bone marrow-derived MSCs (hBMSCs).

\section{Materials and Methods}

\section{Cell culture}

All protocols involving human subjects were approved by the Institutional Review Board of Pusan National University. Cultures of hBMSCs were isolated and characterized according to the methods described in the previous studies [24]. The patients from which bone marrow samples were derived included a 55- 


\section{Cellular Physiology and Biochemistry \\ Cell Physiol Biochem 2012;30:49-60 \\ \begin{tabular}{l|l}
\hline DOI: 10.1159/000339045 & (C) 2012 S. Karger AG, Basel
\end{tabular} \\ Published online: June 8, 2012 \\ www.karger.com/cpb}

year-old man, a 59-year-old woman, and a 48-year-old woman. Mononuclear cells isolated from the bone marrow were separated by centrifugation on a Ficoll-Hypaque gradient (density $=1.077 \mathrm{~g} / \mathrm{cm}^{3}$; Sigma, St Louis, MO, USA), suspended in $\alpha$-minimal essential medium (MEM) containing 10\% FBS, 100 units $/ \mathrm{ml}$ penicillin, and $100 \mu \mathrm{g} / \mathrm{ml}$ streptomycin, and seeded at a concentration of $1 \times 10^{6}$ cells $/ \mathrm{cm}^{2}$. Cultures were maintained at $37^{\circ} \mathrm{C}$ in a humidified atmosphere containing $5 \% \mathrm{CO}$. When the monolayer of adherent cells had reached confluence, cells were trypsinized ( $0.25 \%$ trypsin; Sigma, St Louis, MO, USA), resuspended in $\alpha$-MEM containing $10 \%$ FBS, and subcultured at a concentration of 2,000 cells $/ \mathrm{cm}^{2}$. For the experiment, we used passages 3-5 of hBMSCs. Following incubation, the tissue culture plates were washed to remove residual nonadherent cells and were maintained at $37^{\circ} \mathrm{C}$ under $5 \% \mathrm{CO}_{2}$ in the control medium. Human umbilical vein endothelial cells (HUVECs) were isolated from human umbilical veins by trypsin treatment (1\%) and cultured in M199 medium with $20 \% \mathrm{FCS}, 100 \mathrm{U} / \mathrm{ml}$ penicillin, $100 \mu \mathrm{g} / \mathrm{ml}$ streptomycin, $5 \mathrm{UI} / \mathrm{ml}$ heparin, $12 \mu \mathrm{g} / \mathrm{ml}$ bovine brain extract, and $200 \mathrm{mM}$ glutamine. The HUVECs were grown to confluence in flasks and used at passages 2-5.

\section{Western blot analysis}

The cells were lysed in total cell lysis buffer (containing $210 \mathrm{mM}$ mannitol; $70 \mathrm{mM}$ sucrose; $5 \mathrm{mM}$ Tris, pH 7.5; and $1 \mathrm{mM}$ EDTA), and cellular protein content was determined using a protein assay kit (Bio-Rad Laboratories, Hercules, CA, USA). Proteins were loaded on a $10 \%$ sodium dodecyl sulphatepolyacrylamide gel, electrotransferred to nitrocellulose membranes (Hybond-ECL; Amersham Pharmacia Biotech, Piscataway, NJ, USA), and probed with antibodies (GAPDH, IкB (C-15), total p44/42 map kinase [Erk1/Erk2], antiphospho-ERK [Thr202/204], COX2 (Cell Signaling Technology, Danvers, MA, USA)), total IRAK1 and phospho-IRAK1 (Abcam, Cambridge, UK, USA), and TRADD (Santa Cruz Biotechnology, CA, USA). Immunoreactive bands were detected with an image analyzer (Las-3000 imager, FujiFilm, Japan) by using anti-mouse and anti-rabbit peroxidase-conjugated secondary antibody (Amersham Pharmacia Biotech) and visualized by enhanced chemiluminescence (ECL detection kit; Amersham Pharmacia Biotech).

\section{Immunoprecipitation}

The cells were washed 3 times in PBS (5 min at $600 \times g$ ) and incubated in the presence or absence of TNF (10 ng/ml) for varied lengths of time. The cells were lysed in $3 \mathrm{ml}$ cold RIPA Lysis Buffer (Santa Cruz Biotechnology, Santa Cruz, CA, USA). Lysates were incubated with $10 \mu \mathrm{g}$ of mouse TNFR1 mAbs or mouse IgG control for 2 hours at $4^{\circ} \mathrm{C}$, mixed with $25 \mu \mathrm{l}$ of protein A/G PLUS-agarose (Santa Cruz Biotechnology, Santa Cruz, CA, USA), and incubated overnight. The agarose beads were washed twice with 1 ml lysis buffer, twice with $1 \mathrm{ml}$ high salt ( $1 \mathrm{M} \mathrm{NaCl}$ ) lysis buffer, and an additional 2 times with lysis buffer. The precipitated proteins were analyzed by Western blot using rabbit IRAK1 or TRADD antibodies.

\section{Small interferningRNA transfection transfection}

Small interfering RNA (siRNA) duplex oligonucleotides [on-TARGET plus SMART pool, Thermo Fisher Scientific (Dharmacon, Lafayette, CO, USA), Rockford, IL] of the target genes (IRAK1 and TRADD) mRNA or non-target duplex oligonucleotide (on-TARGET plus siCONTROL, Thermo Fisher Scientific) as a negative control were transfected onto hBMSCs using DharmaFECT Transfection Reagent.

\section{Reporter gene assay}

All transient transfections were performed using Lipofectamine Plus Reagent (Invitrogen, Gaithersburg, MD, USA). The transient transfections were performed using pNF-кB-Luc, pCMV- $\beta$-Gal plasmid (Clontech Laboratories, Inc, Palo Alto, CA, USA). The cells were harvested 48 hours after transfection in $0.25 \mathrm{M}$ Tris, 2 mM DTT, 2 Mm 1,2-diaminocyclohexane-N,N,N',N'-tetraacetic acid, 10\% glycerol, and 1\% Triton X-100 buffer (lysis buffer), and subsequently assayed for luciferase activity (Luciferase Assay System, Promega corporation, Madison, WI, USA). The $\beta$-galactosidase activity was determined using the $\beta$-galactosidase Enzyme Assay System (Promega corporation, Madison, WI, USA). Luciferase activity was normalized by $\beta$-galactosidase activity. Transfections were conducted in duplicate, and all experiments were repeated 4 times.

\section{RT-PCR analysis}

Total cellular RNA was isolated from the cells and reverse transcribed using the conventional protocols. PCRamplification wasperformed using the followingprimersets:GAPDH5'-TCCATGACAACTTTGGTATCG-3',5'- 


\section{Cellular Physiology \\ Cell Physiol Biochem 2012;30:49-60 and Biochemistry

Fig. 1. Effects of TNF- $\alpha$ on IRAK1 phosphorylation in hBMSCs and HUVECs. The hBMSCs (A) and HUVEC (B) cells were treated with TNF- $\alpha(10 \mathrm{ng} / \mathrm{ml})$ for 15 or 30 min. Phosphorylation of IRAK1 was determined by Western blot analysis on cell lysates using anti-phospho-IRAK1 antibody. GAPDH expression was used as a loading control.

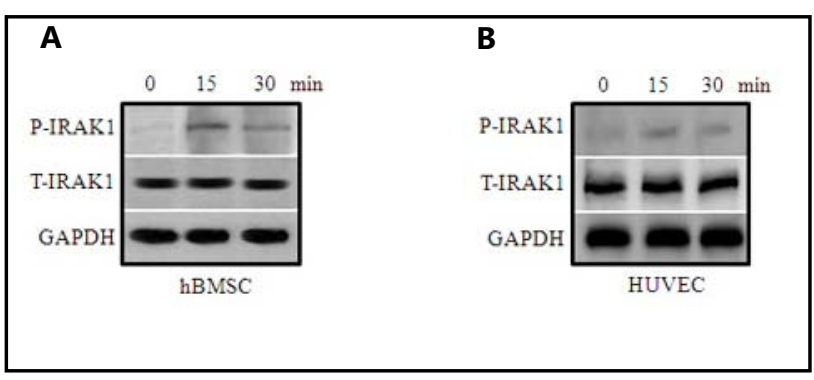

TGTAGCCAAATTCGTTGTCA-3', IRAK1BP1 5'- CGTTTGTCGCCGTCTAGATT-3', 5'-TGGCCAACAAGGTTACAGAC$3^{\prime}$. All primer sequences were determined by using established GenBank sequences. The designed primers were used to amplify the duplicate PCR reactions, and GAPDH was used as a control.

\section{Decoy oligodeoxynucleotide (ODN) technique}

Sequence-specific inhibition of NF-אB can be accomplished using synthetic double-stranded (ds) phosphorothioate oligonucleotides containing a NF- $\kappa$ B consensus sequence, which acts in vivo as a "decoy" cis element to bind transcription factors and block the activation of cognate genes. The sequences for the NF- $\kappa B$ decoy and mutated controls were as follows: NF- $\kappa B$ consensus sequence (5'-AGTTGAGGGGACTTTCCCAGGC$3^{\prime}$ ) and mutated control (5'-AGTTGAGGCGACTTTCCCAGGC-3'). Ds ODNs were prepared from complementary single-stranded phosphorothioate-bonded oligonucleotides by melting them at $95^{\circ} \mathrm{C}$ for 5 minutes, followed by a 3-4-hour reconstitution period at room temperature (RT). The cells were pre-incubated with $10 \mathrm{mM} \mathrm{ds}$ ODN for 24 hours before the treatment of TNF- $\alpha$.

\section{Proliferation assay}

To determine the proliferation rate, hBMSCs were plated at a density of $0.5 \times 10^{4}$ in a 6-well plate. After 72 hours, the cells were trypsinized and stained with $0.4 \%$ trypan blue (Sigma, St Louis, MO, USA). The total cell number was measured using a hemocytometer.

\section{Statistical analysis}

All results are presented as the standard error of the mean (SEM). Comparisons between groups were analyzed using the $t$-test (two-sided) or analysis of variance (for experiments with more than 2 subgroups). Post hoc range tests and pairwise multiple comparisons were conducted using the $t$-test (two-sided) with Turkey adjustment. Probability values of $p<0.05$ were considered statistically significant.

\section{Results}

Effects of IRAK1 modulation on NF- $\kappa B$ activity in TNF- $\alpha$-treated hBMSCs

We first tested whether TNF- $\alpha$ affected the phosphorylation of IRAK1 in hBMSCs and HUVECs. Western blot analysis showed that treatment with $10 \mathrm{ng} / \mathrm{ml}$ TNF- $\alpha$ increased the IRAK1 phosphorylation in hBMSCs and HUVECs (Fig. 1A and 1B).

One of the most important downstream signaling targets activated by TNF- $\alpha$ is the transcription factor NF- $\mathrm{B}$ [25]. We, therefore, tested whether downregulation of IRAK1 or TRADD affected NF- $\kappa$ B activation after TNF- $\alpha$ treatment. Downregulation of IRAK1 or TRADD were confirmed by RT-PCR and western blot analysis (Fig. 2A and 2B). The TNF- $\alpha$ treatment increased the luciferase activity of the NF- $\kappa B$ promoter-luciferase construct, and the downregulation of IRAK1 or TRADD inhibited TNF- $\alpha$-induced NF- $\kappa$ B activation (Fig. 2C). Next, we determined by western blot the effects of downregulated expression of IRAK1 and TRADD on I $\kappa B$ level in the absence or presence of TNF- $\alpha$. The treatment of TNF- $\alpha$ decreased total IKB level in the controls and siIRAK1-transfected cells, whereas downregulation of TRADD blocked TNF- $\alpha$-induced increase of I $\mathrm{B}$ degradation (Fig. 2D).

Because COX-2 is a NF- $\kappa \mathrm{B}$-inducible gene that plays an important role in both inflammation and carcinogenesis [26-27], we investigated whether downregulation of IRAK1 and TRADD would abrogate induction of NF-אB-mediated COX-2. Western blot 


\section{Cellular Physiology Cell Physiol Biochem 2012;30:49-60 \\ \begin{tabular}{ll|l} 
and Biochemistry & $\begin{array}{l}\text { DOI: 10.1159/000339045 } \\
\text { Published online: June 8, 2012 }\end{array}$ & $\begin{array}{l}\text { O 2012 S. Karger AG, Basel } \\
\text { www.karger.com/cpb }\end{array}$ \\
\cline { 2 - 3 } Kim/Cho/Lee/Hong/Yang/Kim/Suh/Jung: The Role of IRAK1 on hBMSCs Proliferation
\end{tabular}}
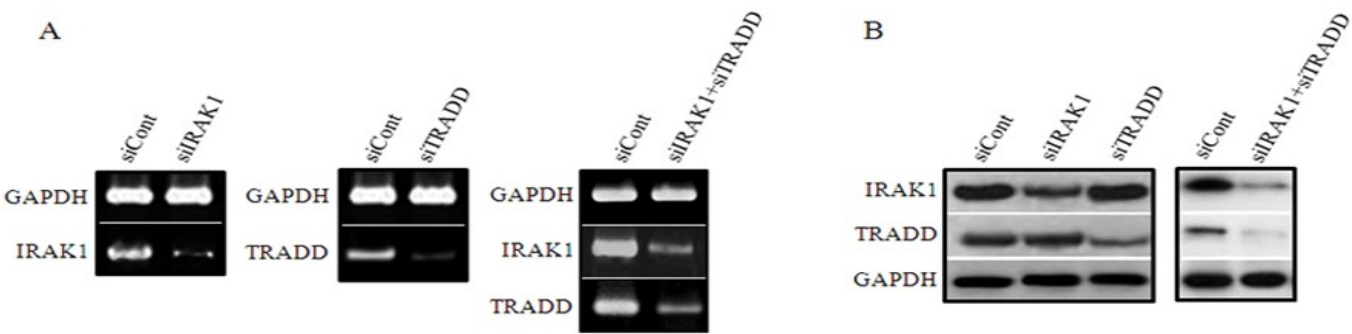

C

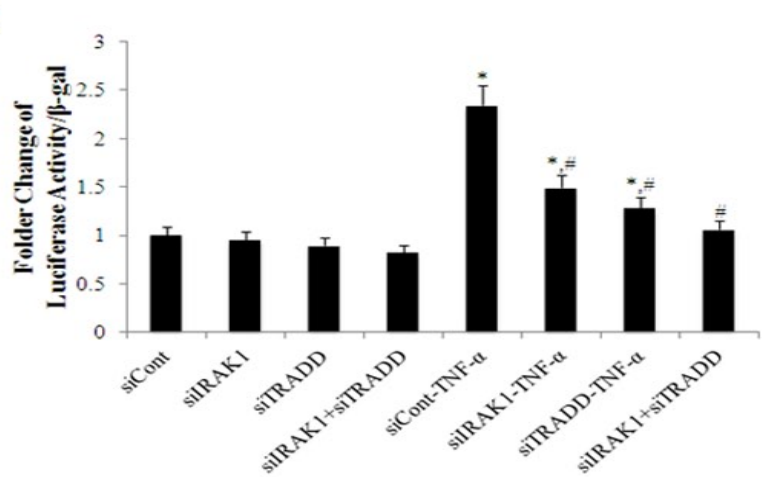

$\mathrm{D}$
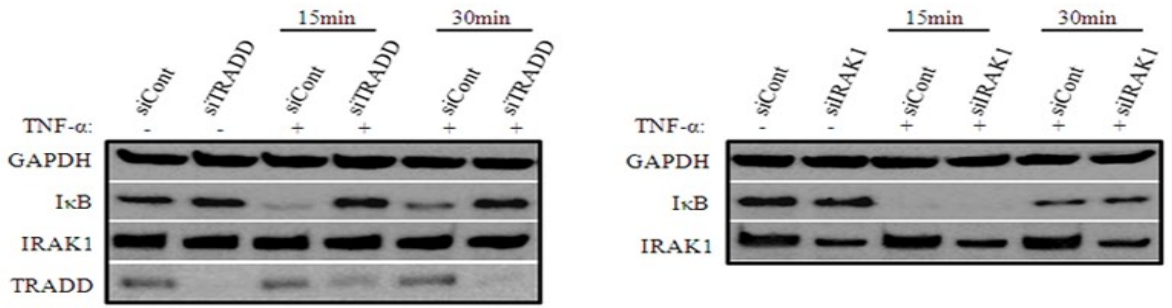

$\mathrm{E}$

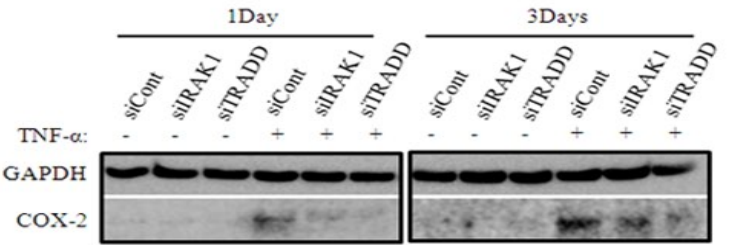

Fig. 2. Effects of IRAK1 and TRADD downregulation on TNF- $\alpha$-induced NF- $\kappa B$ activation in hBMSCs. (A and B) Downregulation of IRAK1 and TRADD expression by siRNA transfection. The expression of IRAK1 and TRADD was determined by RT-PCR (A) and western blot (B). (C) The effects of IRAK1 and TRADD downregulation on TNF- $\alpha$-induced NF- $\kappa B$ promoter activation. The siRNAtransfected cells were co-transfected with NF- $\kappa B$ reporter constructs and $\beta$-gal vectors, and then treated with or without TNF- $\alpha(10 \mathrm{ng} / \mathrm{ml})$ for 48 hours. Luciferase activity was normalized by $\beta$-galactosidase activity. Data represent the mean SEM of 4 independent experiments. ${ }^{*} \mathrm{P}<0.05$, compared to nontarget siRNA-transfected cells (siCont). ${ }^{~} \mathrm{P}<0.05$, compared to the data of TNF- $\alpha$-treated control siRNAtransfected cells (siCont-TNF- $\alpha$ ). (D) The effects of IRAK1 and TRADD downregulation on TNF- $\alpha$-induced IкB levels degradation. The siRNA-transfected hBMSCs were treated with or without TNF- $\alpha(10 \mathrm{ng} / \mathrm{ml})$ for the indicated lengths of time. The expression of IКB, IRAK1, and TRADD was determined by western blot on cell lysates using total anti-IRAK1, anti-IKB, and anti-TRADD antibodies. (E) The effects of IRAK1 and TRADD downregulation on TNF- $\alpha$-induced COX-2 expression. The siRNA-transfected hBMSCs were treated with or without TNF- $\alpha(10 \mathrm{ng} / \mathrm{ml})$ for the indicated lengths of time. Total proteins samples were isolated 1 or 3 days after treatment of TNF- $\alpha$ and was followed by Western blot analysis (E). 


\section{Cellular Physiology Cell Physiol Biochem 2012;30:49-60 \\ \begin{tabular}{ll|l} 
and Biochemistry & $\begin{array}{l}\text { DOI: 10.1159/000339045 } \\
\text { Published online: June 8, 2012 }\end{array}$ & $\begin{array}{l}\text { O 2012 S. Karger AG, Basel } \\
\text { www.karger.com/cpb }\end{array}$ \\
\end{tabular}}

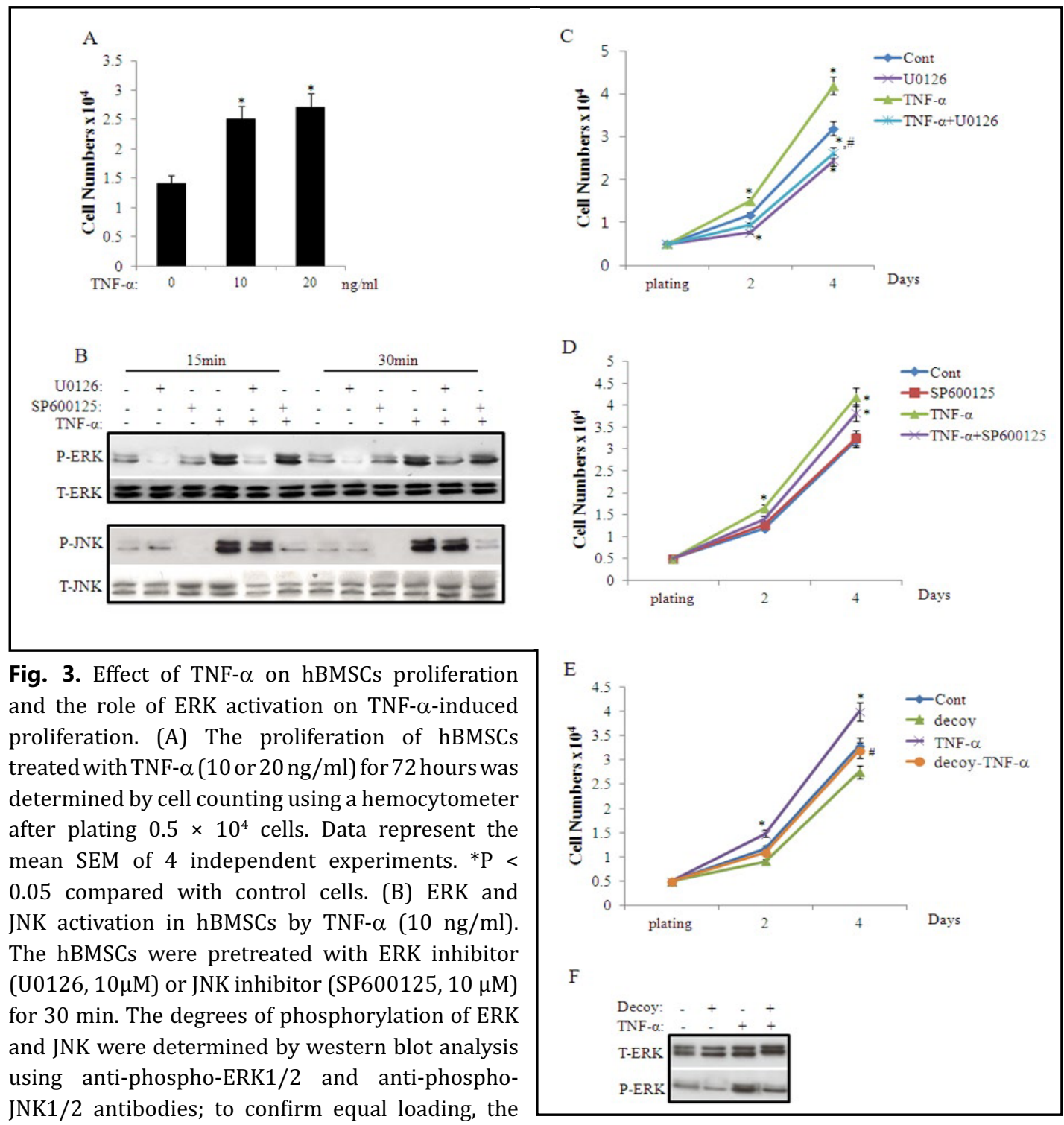

JNK1/2 antibodies; to confirm equal loading, the quantities of ERK and JNK were probed by treatment with anti-ERK and anti-JNK1/2 antibody. (C, D) The effects of ERK and JNK inhibitor on TNF- $\alpha$-induced proliferation of hBMSCs. U0126 (C) and SP600125 (D) were after plating $0.5 \times 10^{4}$ cells in the absence or presence of TNF- $\alpha(10 \mathrm{ng} / \mathrm{ml})$. Cell proliferation was analyzed on days 2 and 4 by total cell counting assay. Data represent the mean SEM of 4 independent experiments. ${ }^{*} \mathrm{P}<0.05$ compared to control cells (Cont). ${ }^{*} \mathrm{P}<0.05$ versus treatment with TNF- $\alpha$ on control cells (TNF- $\alpha$ ). (E) Effect of NF- $\kappa B$ decoy oligonucleotides on TNF- $\alpha$-induced proliferation of hBMSCs. NF- $\kappa B$ decoy oligonucleotides $(10 \mu \mathrm{M})$ was pretreated in hBMSCs for 24 hours before adding TNF- $\alpha(10 \mathrm{ng} / \mathrm{ml})$. Cell numbers wer analyzed on days 2 and 4 after cell plating. Data represent the mean SEM of 4 independent experiments. ${ }^{*} \mathrm{P}<0.05$ compared to control oligo-treated cells (Cont). (F) The effect of NF- $\kappa B$ decoy on TNF- $\alpha$-induced ERK activation in hBMSCs. The hBMSCs were pretreated with NF- $\kappa B$ decoy for 24 hours, and the degree of phosphorylation of ERK was determined by western blot analysis of cell lysates with antiphospho-ERK1/2 antibody; to confirm equal loading, the quantity of ERK was probed by treatment using an anti-ERK antibody.

analysis showed that TNF- $\alpha$ treatment increased the expression of COX- 2 after 3 days, and the downregulation of IRAK1 and TRADD by siRNA blocked the TNF- $\alpha$-induced increase in COX-2 expression (Fig 2E). 


\section{Cellular Physiology $\quad$ Cell Physiol Biochem 2012;30:49-60 \\ \begin{tabular}{ll|l} 
and Biochemistry & $\begin{array}{l}\text { DOI: 10.1159/000339045 } \\
\text { Published online: June 8, 2012 }\end{array}$ & $\begin{array}{l}\text { O 2012 S. Karger AG, Basel } \\
\text { www.karger.com/cpb }\end{array}$ \\
\cline { 2 - 3 } Kim/Cho/Lee/Hong/Vang/Kim/Suh/Jung: The Role of IRAK1 on hBMSCs Proliferation
\end{tabular}}

Fig. 4. Effects of IRAK1 and TRADD d o w n r e g u l a ti o n on TNF- $\alpha$-induced hBMSCs proliferation. (A) The hBMSCs were transfected with IRAK1 or TRADD SiRNA or non-target control siRNA oligonucleotides, treated with TNF- $\alpha(10$ $\mathrm{ng} / \mathrm{ml}$ ) and cell numbers were counted (A, B). Data represent the mean SEM of 4 independent experiments. ${ }^{*} \mathrm{P}<0.05$, compared to control siRNA-transfected cells (siCont). ${ }^{\#} \mathrm{P}<0.05$, compared to the data of TNF- $\alpha$-treated control siRNA-transfected cells (siCont-TNF- $\alpha$ ). EffectofIRAK1orTRADD inhibition on ERK or JNK phosphorylation. Phosphorylation levels of ERK and JNK were analyzed at 15 or $30 \mathrm{~min}$ after TNF- $\alpha$ treatment. To confirm equal loading, the quantities of ERK and JNK were probed by treatment with anti-ERK and antiJNK antibodies.

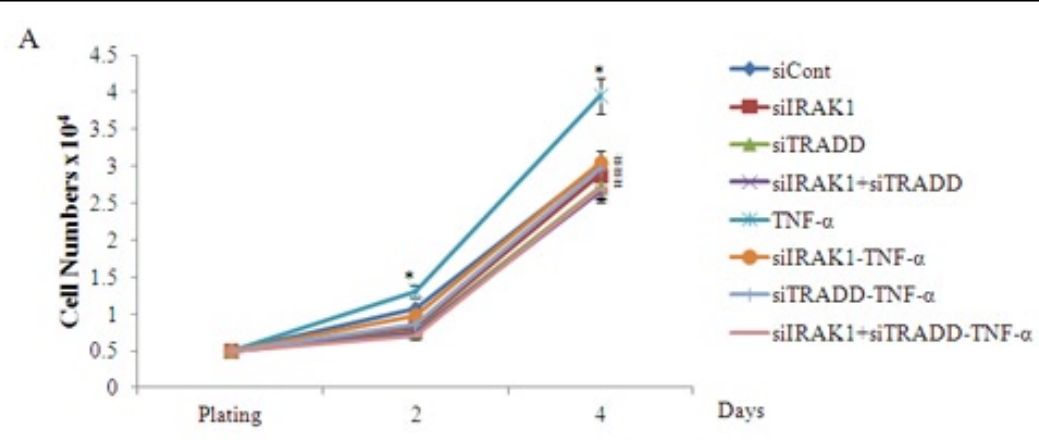

B
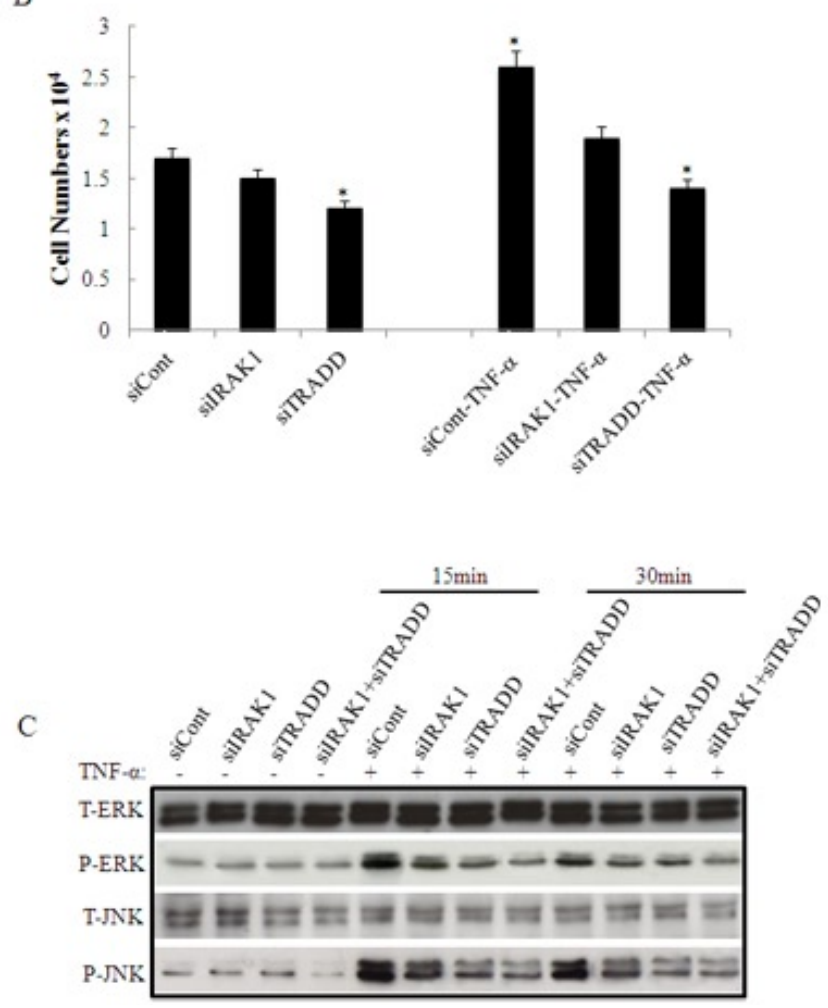

Fig. 5. with TNFR1 and IRAK1 in BMSCs. The cells were treated with TNF- $\alpha$, and harvested $15 \mathrm{~min}$ or 30min later. Cell lysates were pre. Analysis of physical interaction pared, and TNFR1 and IgG control antibodies were used to generate immunocomplexes. The immunocomplexes were analyzed by western blot analysis for physical binding of IRAK1, TRADD, and TNFR1. GAPDH expression was used as a loading control.

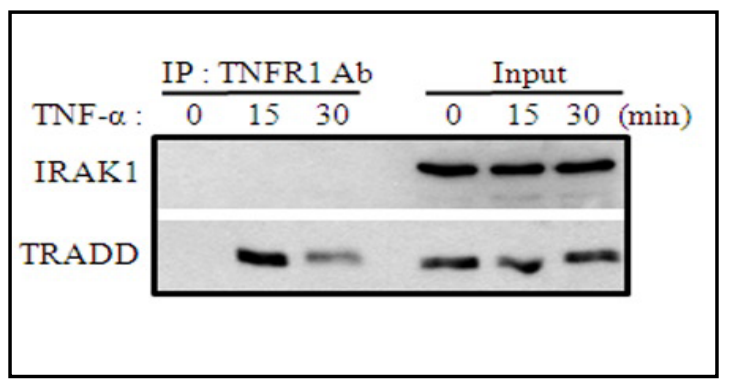

ERK mediated signaling on TNF- $\alpha$-induced $h B M S C$ s proliferation

To determine the effect of TNF- $\alpha$ on hBMSCs proliferation, hBMSCs were treated with TNF- $\alpha$ (10 or $20 \mathrm{ng} / \mathrm{ml}$ ) for 72 hours. The TNF- $\alpha$ treatment of hBMSCs significantly 


\section{Cellular Physiology Cell Physiol Biochem 2012;30:49-60 \\ \begin{tabular}{ll|l} 
and BiOChemistry & $\begin{array}{l}\text { DOI: 10.1159/000339045 } \\
\text { Published online: June 8, 2012 }\end{array}$ & $\begin{array}{l}\text { C 2012 S. Karger AG, Basel } \\
\text { www.karger.com/cpb }\end{array}$ \\
\cline { 2 - 2 } Kim/Cho/Lee/Hong/Yang/Kim/Suh/Jung: The Role of IRAK1 on hBMSCs Proliferation
\end{tabular}}

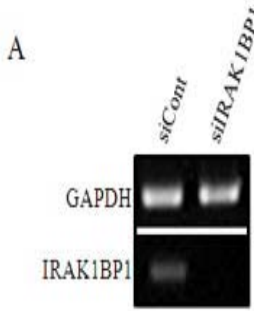

\section{B}

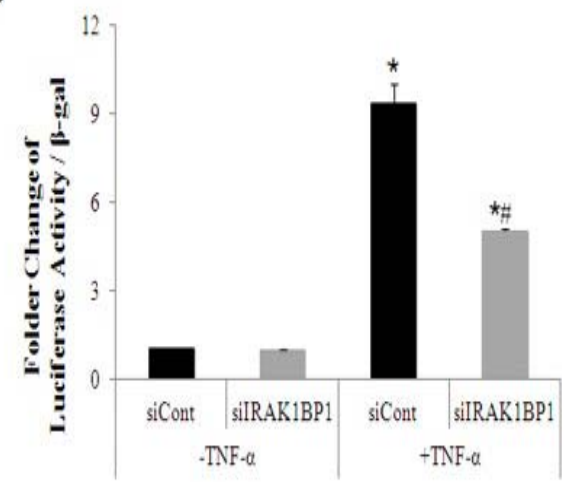

C

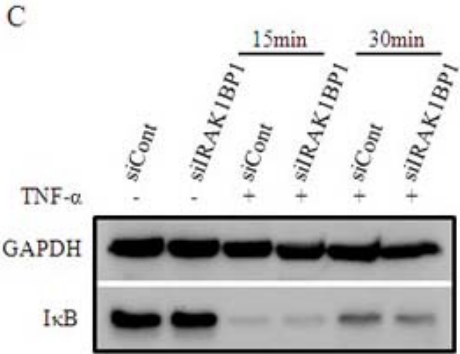

Fig. 6. Effect of IRAK1BP1 inhibition on TNF- $\alpha$-induced NF- $\kappa B$ activity and I $\kappa B$ degradation. (A) Inhibition of IRAK1BP1 expression by siRNA was confirmed by RT-PCR. (B) NF- $\kappa$ B activity was measured by luciferase assay at 48 hours after the treatment of TNF- $\alpha(10 \mathrm{ng} / \mathrm{ml})$. Data represent the mean SEM of 4 independent experiments. ${ }^{*} \mathrm{P}<0.05$, compared to control siRNA-transfected cells (siCont). ${ }^{*} \mathrm{P}<0.05$, compared to the data of TNF- $\alpha$-treated control siRNA-transfected cells (siCont-TNF- $\alpha$ ). (C) The siRNA-transfected hBMSCs were treated with or without TNF- $\alpha(10 \mathrm{ng} / \mathrm{ml})$ for the indicated lengths of time. The expression level of IкB was determined by Western blot on cell lysates using IкB antibody.

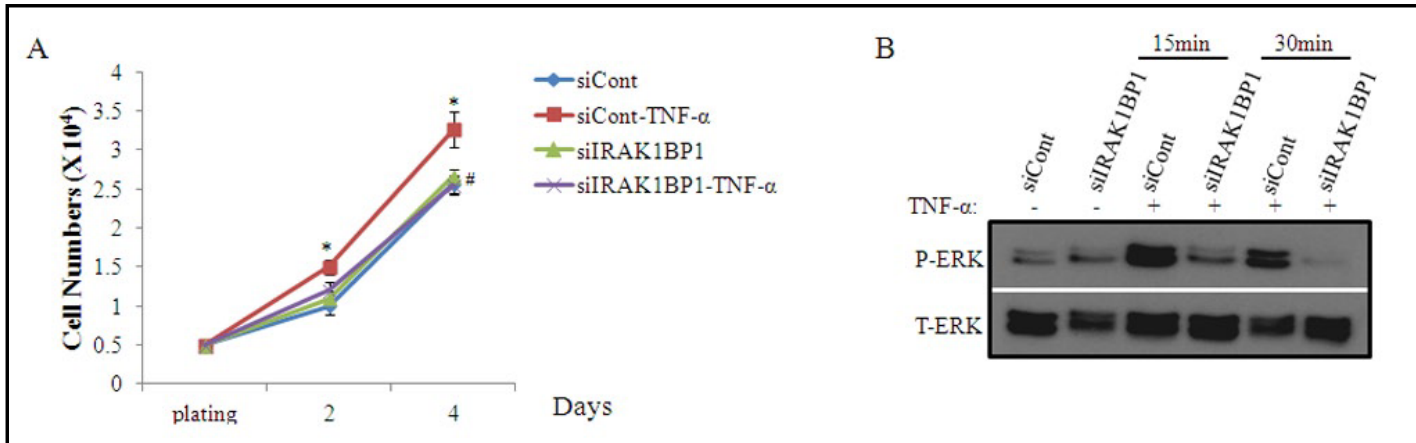

Fig. 7. Effect of IRAK1BP1 inhibition on hADSC proliferation and ERK activation induced by TNF- $\alpha$. (A) Numbers of hBMSCs were determined on day 2 and 4 after plating of $5 \times 10^{3}$ cells in the absence or presence of TNF- $\alpha(10 \mathrm{ng} / \mathrm{ml})$. Data represent the mean SEM of 4 independent experiments. ${ }^{*} \mathrm{P}<0.05$ compared to control cells (siCont). (B) Phosphorylation levels of ERK were analyzed at 15 or 30 min after TNF- $\alpha$ treatment $(10 \mathrm{ng} / \mathrm{ml})$ in siControl or siIRAK1BP1-transfected cells.

increased their proliferation in a dose-dependent manner (Fig. 3A). Because TNF- $\alpha$ stimulates the activation of the MAPK and the NF- $\mathrm{BB}$ signaling pathway in other cell types [28-30], we investigated whether ERK1/2, JNK, and NF- $\kappa B$ activation were dependent on TNF- $\alpha$ stimulation leading to proliferation of hBMSCs. We first determined whether TNF$\alpha$ would stimulate ERK1/2, JNK, and NF- $\mathrm{KB}$ activation in hBMSCs. Basal ERK1/2 and JNK 


\section{Cellular Physiology and Biochemistry \\ Cell Physiol Biochem 2012;30:49-60 \\ \begin{tabular}{l|l}
\hline DOI: $10.1159 / 000339045$ & C 2012 S. Karger AG, Basel
\end{tabular} \\ Published online: June 8, 2012 \\ www.karger.com/cpb}

phosphorylation, and NF- $\kappa$ B activation increased in TNF- $\alpha$-treated hBMSCs (Fig. 3B and 2C), and pretreatment with U0126 and SP60012, ERK and JNK inhibitors respectively, blocked TNF- $\alpha$-mediated activation of MAPKs (Fig. 3B). Next, proliferation was determined by total cell counts at 2 and 4 days after plating $0.5 \times 10^{4}$ cells. U0126 $(10 \mu \mathrm{M})$ significantly decreased hBMSCs proliferation and blocked TNF- $\alpha$-induced hBMSCs proliferation (Fig. $3 \mathrm{C}$ ), while the JNK inhibitor had no significant effects on hBMSCs proliferation (Fig. 3D). The treatment

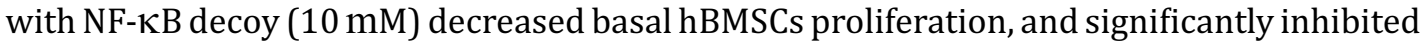
TNF- $\alpha$-induced hBMSCs proliferation (Fig. 3E). To determine the relationship between NF$\kappa B$ activation and ERK activation in hBMSCs, we measured the effect of the NF- $\kappa B$ decoy on ERK phosphorylation. The treatment with NF- $\mathrm{BB}$ decoy inhibited basal and TNF- $\alpha$-induced ERK activation in hBMSCs (Fig. 3F).

\section{Effect of IRAK1 regulation on TNF- $\alpha$ induced hBMSCs proliferation}

We then determined whether downregulation of IRAK1 or TRADD would affect TNF$\alpha$-induced hBMSCs proliferation. Downregulation of IRAK1 or TRADD did not affect basal hBMSCs proliferation but did inhibit TNF- $\alpha$-induced hBMSCs proliferation (Fig. 4A). In IRAK1 or TRADD downregulated cells, treatment with U0126 inhibited hBMSCs proliferation and significantly blocked TNF- $\alpha$-induced hBMSCs proliferation (Fig. 4B). To determine the effect of downregulation of IRAK1 or TRADD on level of ERK and JNK after TNF- $\alpha$ treatment, siRNA transfected hBMSCs were treated with TNF- $\alpha$ for the indicated length of time. Although downregulation of IRAK1 or TRADD did not affect ERK and JNK activation in TNF- $\alpha$ not treated hBMSCs, TNF- $\alpha$-induced ERK and JNK activation were inhibited (Fig. 4C).

In order to explore the possible interaction between IRAK1 and TNFR1 in TNF- $\alpha$-treated hBMSCs, we performed immunoprecipitation experiments. In the immunoprecipitation assays, we precipitated proteins from lysates of control hBMSCs and TNF- $\alpha$-treated hBMSCs with TNFR1-specific antibodies and then analyzed by western blot. As shown in Fig. 5, IRAK1 was not associated with TNFR1 even in the presence of TNF- $\alpha$, whereas TRADD was bound with TNFR1 in of TNF- $\alpha$ treated BMSCs.

\section{Effect of IRAK1BP1 downregulation of TNF- $\alpha$-induced proliferation}

IRAK1BP1 is an IRAK1 binding protein and interacts with p65 in a TNF- $\alpha$-dependent manner [31]. To understand the role of IRAK1BP1 on TNF- $\alpha$-induced activation of NF- $\kappa B$ in hBMSCs and their proliferation, RT-PCR analysis showed that siRNA transfection decreased the expression level of IRAK1BP1 mRNA in hBMSCs (Fig. 6A). This inhibition of IRAK1BP1 significantly decreased the activity of NF- $\kappa B$ binding promoter only in the TNF- $\alpha$-treated cells (Fig. 6B), but did not affect TNF- $\alpha$-induced degradation of IKB (Fig. 6C). The proliferation of hBMSCs was suppressed by IRAK1BP1 inhibition only in the presence of TNF- $\alpha$ (Fig. 7A). To further confirm the role of IRAK1BP1 on TNF signaling in hBMSCs, we determined the effect of IRAK1BP1 downregulation on ERK activity. Western blot analysis showed that TNF- $\alpha$ induced ERK1 phosphorylation was blocked by the downregulation of IRAK1BP1 (Fig. 7B).

\section{Discussion}

The data in this study showed that treatment of TNF- $\alpha$ induces phosphorylation of IRAK1, and the downregulation of IRAK1 expression by siRNA technology blocks TNF- $\alpha$ -

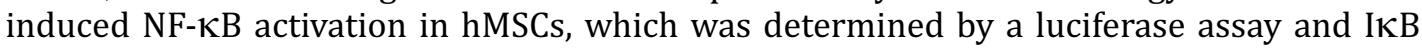
degradation. These results indicate that IRAK1 is an important component of the TNF- $\alpha$ mediated NF- $\kappa B$ activation pathway. The important role of IRAK1 in the TNF- $\alpha$-mediated NF- $\kappa B$ activation was further supported by the finding that downregulation of IRAK1 blocks the TNF- $\alpha$-induced increase in the expression of COX2, which is a well-known downstream target of NF- $\kappa B$ activation. We previously reported that downregulation of IRAK1 by overexpression of Mir-146 inhibits the NF- $\mathrm{KB}$ induced increase in osteogenic differentiation of hADSCs [11]. These findings indicated that the catalytic activity of mPLK/IRAK1 is critical to the TNF signaling pathway. 


\section{Cellular Physiology and Biochemistry \\ Cell Physiol Biochem 2012;30:49-60 \\ \begin{tabular}{l|l}
\hline DOI: $10.1159 / 000339045$ & C 2012 S. Karger AG, Basel
\end{tabular} \\ Published online: June 8, 2012 \\ www.karger.com/cpb}

A growing body of evidence suggests the importance of IRAK1 on TNFR1 signaling [3233] since Vig et al. first reported that the inhibition of IRAK1 by the transfection of negative dominant IRAK1 blocks TNF- $\alpha$-induced activation of NF- $\kappa B$ in mouse embryonic fibroblast cells [23]. The role of IRAK1 on TNFR1 signaling in vivo was also observed in IRAK1 null/ TNF- $\alpha$ transgenic mice. Thomas et al. reported that IRAK1 inactivation prolongs survival in mice that overexpress TNF- $\alpha$ in the hear [34].

The effect of TNF- $\alpha$ on BMSCs proliferation is controversial. Bocker et al. showed that TNF- $\alpha$ increases the invasive and proliferative properties of hBMSCs [12]. However, Ghali et al. reported that TNF- $\alpha$ exerts antiproliferative and apoptotic effects by RUNX2-dependent mechanisms [13]. This discrepancy may have resulted from the experimental conditions used to determine cell proliferation. Bocker et al. treated cells with $10 \mathrm{ng} / \mathrm{ml}$ TNF- $\alpha$ in culture media containing 10\% FBS for 24 hours [12], but Ghali et al. treated cells with the same concentration of TNF- $\alpha$ in the presence of $0.5 \%$ FCS for up to 5 days [13]. In this study, we treated hBMSCs with TNF- $\alpha$ in the presence of $10 \%$ FBS and observed that TNF- $\alpha$ increases the proliferation of hBMSCs in a dose-dependent manner, which is consistent with the findings of Bocker et al [12].

In this study, the TNF- $\alpha$-induced increase in hBMSCs proliferation was blocked by the downregulation of IRAK1 and by the downregulation of TRADD1. The kinase assay revealed that the downregulation of IRAK1 or TRADD1 inhibited TNF- $\alpha$-induced activation of ERK1/2 and JNK. Although the JNK inhibitor did not affect TNF- $\alpha$-induced proliferation of hBMSCs, the ERK1/2 inhibitor blocked TNF- $\alpha$ induced hBMSCs proliferation. Bocker et al. showed that downregulation of IKK-2 blocks the TNF- $\alpha$-induced increase in cell proliferation, which suggests the important role of the canonical NF- $\kappa B$ pathway [12]. In our study, transfection with decoy oligonucleotides for NF- $\kappa B$ inhibition decreased the TNF- $\alpha$-induced increase in cell proliferation and the activation of ERK in hBMSCs. These data indicated that TNF- $\alpha-$ induced cell proliferation is mediated by the NF- $\mathrm{BB}$-induced activation of ERK1/2 in hBMSCs, providing evidence that the IRAK1 plays a major role, along with the TNFR1-TRADD complex, in the TNF- $\alpha$-induced proliferation.

Activated IRAK1 makes complex with TRAF6 to activate downstream pathway [35]. However, our data showed that IRAK1 activated by TNF- $\alpha$ does not bind to TRAF6 (Fig. $5 B)$. This result suggests the presence of new mechanism by which IRAK1 activates NF- $\kappa B$ pathway. Interestingly, immunoprecipitation using mouse TNFR1 antibody showed that, in contrast with TRADD, IRAK1 does not physically bind to TNFR1 in the absence or presence of TNFR1 which is a critical receptor for soluble TNF- $\alpha$ and initiates TNF signaling cascade (Fig. 5A). In this experiment, we used mouse-derived antibody in immunoprecipitation and rabbit-derived antibody in Western blot analysis to exclude nonspecific cross-reactive bands to IgG, because the molecular weight of IRAK1 is similar to that of the heavy chain of IgG. Further studies are required to verify the potential upstream kinase for IRAK1, which is activated by TNFR1.

In contrast, Vig et al. reported the presence of IRAK1 protein in the immunocomplexes generated with the TNFRI antisera in unstimulated mouse fibroblasts and showed that the amount of mPLK protein associated with TNFRI appeared to increase in response to TNF treatment [23]. This difference may result from the difference of cells to be used in the experiment.

The loss of substrate that interacts with interleukin-1 receptor-associated kinase binding protein 1 (IRAK1BP1, also known as mouse pelle-like kinase (SIMPL) specifically inhibits the TNF- $\alpha$-dependent TNFR1-dependent response in mouse embryo fibroblasts $[31,36]$ and in mouse hematopoietic progenitors [37]. In this study, we showed that the downregulation of IRAK1BP1 by siRNA transfection blocked NF- $\mathrm{KB}$ activation, proliferation and ERK1 activation which were induced by the addition of TNF- $\alpha$ in hBMSCs. These data indicated that the role of IRAK1 on TNF- $\alpha$ signaling in hBMSCs is mediated through the activation of IRAK1BP1. It has been reported that the IRAK1 catalytic activity phosphorylates IRAK1BP1, a p65-specific coactivator, and that the subsequent nuclear localization of phosphorylated IRAK1BP1 is required for full activation of NF-кB-inducible genes [31, 32]. The data in this 


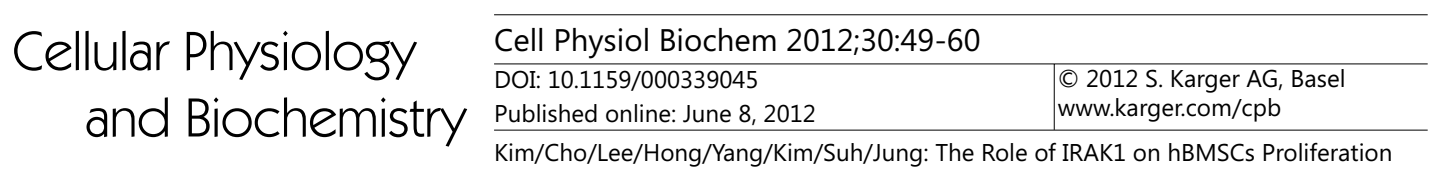

study showed that the downregulation of IRAK1 and IRAK1BP1did not affect TNF- $\alpha$-induced I $\mathrm{B}$ degradation, supporting that IRAK1 and IRAK1BP1 modulate TNF- $\alpha$ signaling pathways distal to I $\kappa$ B degradation processes.

In summary, we showed that IRAK1 plays an important role in TNF- $\alpha$-induced NF- $\kappa B$ activation and proliferation in hMSCs.

\section{Acknowledgements}

This study was supported by the MRC program of MEST/KOSEF (2011-0006192).

\section{References}

1 Gimble JM, Bunnell BA, Casteilla L, Jung JS, Yoshimura K: Phases I-III Clinical Trials Using Adult Stem Cells. Stem Cells Int 2010:604713.

2 Bruunsgaard H, Pedersen M, Pedersen BK: Aging and proinflammatory cytokines. Curr Opin Hematol 2001;8:31-136.

3 Zhang A, Wang Y, Ye Z, Xie H, Zhou L, Zheng S: Mechanism of TNF- $\alpha$-induced migration and hepatocyte growth factor production in human mesenchymal stem cells. J Cell Biochem 2010:111:469-475.

4 Abshagen K, Eipel C, Kalff JC, Menger MD, Vollmar B: Loss of NF- $\kappa B$ activation in Kupffer cell-depleted mice impairs liver regeneration after partial hepatectomy. Am J Physiol Gastrointest Liver Physiol 2007;292: G1570-G1577.

5 Wang M, Crisostomo PR, Herring C, Meldrum KK, Meldrum DR: Human progenitor cells from bone marrow or adipose tissue produce VEGF, HGF, and IGF-I in response to TNF by a p38 MAPK-dependent mechanism. Am J Physiol Regul Integr Comp Physiol 2006;291:R880-R884.

6 Wang Y, Weil BR, Herrmann JL, Abarbanell AM, Tan J, Markel TA, Kelly ML, Meldrum DR: MEK, p38, and PI-3K mediate cross talk between EGFR and TNFR in enhancing hepatocyte growth factor production from human mesenchymal stem cells. Am J Physiol Cell Physiol 2009;297:C1284-C1293.

7 Kim YS, Park HJ, Hong MH, Kang PM, Morgan JP, Jeong MH, Cho JG, Park JC, Ahn Y: TNF- $\alpha$ enhances engraftment of mesenchymal stem cells into infarcted myocardium. FrontBiosci 2009;14:2845-2856.

8 Tan J, Weil BR, Abarbanell AM, Wang Y, Herrmann JL, Dake ML, Meldrum DR: Ablation of TNF- $\alpha$ receptors influences mesenchymal stem cell-mediated cardiac protection against ischemia. Shock 2010;34:236-242.

$9 \mathrm{Xu} \mathrm{H}$, Sethi JK, Hotamisligil GS: Transmembrane tumor necrosis factor (TNF)- $\alpha$ inhibits adipocyte differentiation by selectively activating TNF receptor 1. J Biol Chem 1999;274:26287-26295.

10 Filipak M, Sparks RL, Tzen CY, Scott RE: Tumor necrosis factor inhibits the terminal event in mesenchymal stem cell differentiation. J Cell Physiol 1988;137:367-373.

11 Cho HH, Shin KK, Kim YJ, Song JS, Kim JM, Bae YC, Kim CD, Jung JS: NF- $\kappa B$ activation stimulates osteogenic differentiation of mesenchymal stem cells derived from human adipose tissue by increasing TAZ expression. J Cell Physiol 2010;223:168-177.

12 Bocker W, Docheva D, Prall WC, Egea V, Pappou E, Rossmann O, Popov C, Mutschler W, Ries C, Schieker M: IKK-2 is required for TNF- $\alpha$-induced invasion and proliferation of human mesenchymal stem cells. J Mol Med (Berl) 2008;86:1183-1192.

13 Ghali O, Chauveau C, Hardouin P, Broux O, Devedjian JC: TNF-alpha's effects on proliferation and apoptosis in human mesenchymal stem cells depend on RUNX2 expression. J Bone Miner Res 2010;25:1616-1626.

14 Jiang Y, Woronicz JD, Liu W, Goeddel DV: Prevention of constitutive TNF receptor 1 signaling by silencer of death domains. Science 1999;283:543-546.

15 Hsu H, Xiong J, Goeddel DV: The TNF receptor 1-associated protein TRADD signals cell death and NF- $\kappa B$ activation. Cell 1995;81:495-504.

16 Hsu H, Huang J, Shu HB, Baichwal V, Goeddel DV: TNF-dependent recruitment of the protein kinase RIP to the TNF receptor-1 signaling complex. Immunity 1996;4:387-396.

17 Hsu H, Shu HB, Pan MG, Goeddel DV: TRADD-TRAF2 and TRADD-FADD interactions define two distinct TNF receptor 1 signal transduction pathways. Cell 1996;84:299-308. 


\section{Cellular Physiology and Biochemistry \\ Cell Physiol Biochem 2012;30:49-60 \\ \begin{tabular}{l|l}
\hline DOI: $10.1159 / 000339045$ & (c) 2012 S. Karger AG, Basel
\end{tabular} \\ Published online: June 8, 2012 \\ www.karger.com/cpb}

18 Shu HB, Takeuchi M, Goeddel DV: The tumor necrosis factor receptor 2 signal transducers TRAF2 and cIAP1 are components of the tumor necrosis factor receptor 1 signaling complex. Proc Natl Acad Sci USA 1996;93:13973-13978.

19 Lee TH, Huang Q, Oikemus S, Shank J, Ventura JJ, Cusson N, Vaillancourt RR, Su B, Davis RJ, Kelliher MA: The death domain kinase RIP1 is essential for tumor necrosis factor alpha signaling to p38 mitogen-activated protein kinase. Mol Cell Biol 2003;23:8377-8385.

20 Winston BW, Lange-Carter CA, Gardner AM, Johnson GL, Riches DW: Tumor necrosis factor alpha rapidly activates the mitogen-activated protein kinase (MAPK) cascade in a MAPK kinase kinase-dependent, c-Raf1-independent fashion in mouse macrophages. Proc Natl Acad Sci U S A 1995;92:1614-1618.

21 Schievella AR, Chen JH, Graham JR, Lin LL: MADD, a novel death domain protein that interacts with the type 1 tumor necrosis factor receptor and activates mitogen-activated protein kinase. J Biol Chem 1997;272:12069-12075.

22 Gottipati S, Rao NL, Fung-Leung WP: IRAK1: a critical signaling mediator of innate immunity. Cell Signal 2008;20:269-276.

23 Vig E, Green M, Liu Y, Donner DB, Mukaida N, Goebl MG, Harrington MA: Modulation of tumor necrosis factor and interleukin-1-dependent NF- $\kappa B$ activity by mPLK/IRAK. J Biol Chem 1999;274:13077-13084.

24 Lee RH, Kim B, Choi I, Kim H, Choi HS, Suh K, Bae YC, Jung JS: Characterization and expression analysis of mesenchymal stem cells from human bone marrow and adipose tissue. Cell Physiol Biochem 2004;14:311324.

$25 \mathrm{Li} \mathrm{H}$, Lin X: Positive and negative signaling components involved in TNF $\alpha$-induced NF- $\mathrm{KB}$ activation. Cytokine 2008;41:1-8.

26 Yamamoto K, Arakawa T, Ueda N, Yamamoto S: Transcriptional roles of nuclear factor $\mathrm{\kappa B}$ and nuclear factor-interleukin- 6 in the tumor necrosis factor $\alpha$-dependent induction of cyclooxygenase- 2 in MC3T3-E1 cells. J Biol Chem1995; 270:31315-31320.

27 Jung YJ, Isaacs JS, Lee S, Trepel J, Neckers L: IL-1beta-mediated up-regulation of HIF-1 $\alpha$ via an NF- $\mathrm{KB}$ / COX-2 pathway identifies HIF-1 as a critical link between inflammation and oncogenesis. FASEB J 2003;17:2115-2117.

28 Yin Y, Wang S, Sun Y, Matt Y, Colburn NH, Shu Y, Han X: JNK/AP-1 pathway is involved in tumor necrosis factor- $\alpha$ induced expression of vascular endothelial growth factor in MCF7 cells. Biomed Pharmacother 2009;63:429-435.

29 Seger R, Krebs EG: The MAPK signaling cascade. FASEB J 1995;9:726-735.

30 Liu ZG, Han J: Cellular responses to tumor necrosis factor. Curr Issues Mol Biol 2001;3:79-90.

31 Kwon HJ, Breese EH, Vig-Varga E, Luo Y, Lee Y, Goebl MG, Harrington MA: Tumor necrosis factor $\alpha$ induction of NF- $\kappa$ B requires the novel coactivator SIMPL. Mol Cell Biol 2004;24:9317-9326.

32 Luo Y, Kwon HJ, Montano S, Georgiadis M, Goebl MG, Harrington MA: Phosphorylation of SIMPL modulates RelA-associated NF-кB-dependent transcription. Am J Physiol Cell Physiol 2007;292:C1013-1023.

33 Thomas JA, Allen JL, Tsen M, Dubnicoff T, Danao J, Liao XC, Cao Z, Wasserman SA: Impaired cytokine signaling in mice lacking the IL-1 receptor-associated kinase. J Immunol 1999;163:978-984.

34 Thomas JA, Haudek SB, Koroglu T, Tsen MF, Bryant DD, White DJ, Kusewitt DF, Horton JW, Giroir BP: IRAK1 deletion disrupts cardiac Toll/IL-1 signaling and protects against contractile dysfunction. Am J Physiol Heart Circ Physiol 2003;285:H597-606.

35 Chen ZJ: Ubiquitin signalling in the NF-kappaB pathway. Nat Cell Biol 2005;7:758-765.

36 Vig E, Green M, Liu Y, Yu KY, Kwon HJ, Tian J, Goebl MG, Harrington MA: SIMPL is a tumor necrosis factorspecific regulator of nuclear factor- $\kappa B$ activity. J Biol Chem 2001;276:7859-7866.

37 Benson EA, Goebl MG, Yang FC, Kapur R, McClintick J, Sanghani S, Clapp DW, Harrington MA: Loss of SIMPL compromises TNF- $\alpha$-dependent survival of hematopoietic progenitors. Exp Hematol 2010;38:71-81. 